

\title{
Five years of the Journal of Science, Humanities, and Arts - JOSHA-
}

\author{
Happy New Year to all our readers!
}



The journal has grown over the last 5 years and it is all thanks to the support of everyone on this team, that is, thanks to our writers, readers, specialists and administrative team. The journey that JOSHA has made over these years has allowed them to extend their roots and contacts thanks to people in different parts of the world.

JOSHA is a novel interdisciplinary, multi-language, open-access internet platform dedicated to rapidly communicate knowledge of all fields of science, humanities, and arts. JOSHA's publication concept is based on the awareness that universal access to knowledge is the fundamental principle of science, humanities and arts. The journal has the specific goal to provide a fair mode of low-cost publication for the broad diversity of important discoveries and creativity of humans by avoiding any loss of knowledge, loss of copyrights for authors and flaws due to old-style peer-review procedures.

JOSHA was initiated by Roland Mertelsmann in 2014 and stands in the tradition of the journal "Isis", the first multidisciplinary journal in the German language founded in 1816, published by Friedrich Arnold Brockhaus and edited by Lorenz Oken (1779 - 1851), a German physician, natural philosopher, researcher, biologist, anatomist and physiologist who published from 1816 to 1848 , contributions to natural sciences, medicine, technology, economy, arts, history, science policy, and science organization. 
JOSHA was originally founded under German law as "Gesellschaft mit beschränkter Haftung $\underline{(\mathrm{GmbH})}$ " in Freiburg, Germany. Founding shareholders and founding editors included jurisprudent Günter Hager $(\dagger)$, philosopher Felicitas Holzer, data scientist Sascha Lange, hematologist, and oncologist Roland Mertelsmann, history of art specialist Stephan Seiler, and pathologist and psychologist Gerhard Steinmann. JOSHA GmbH developed technical background, software and layout design as well as legal, licensing and submission terms. The first issue appeared in December 2014 under http://www.josha-journal.org.

In 2015, the International Academy of Science, Humanities, and Arts (IASHA e.V.), a non-profit association in Freiburg, Germany (https://www.iasha.org), became the publisher of JOSHA. Since then, JOSHA is operated as a non-profit journal supported by voluntary and tax-deductible donations. Annual reports of IASHA e.V. are regularly published in JOSHA. Membership in IASHA e.V. is open to any interested person, company or association.

JOSHA's permanent Editorial Board includes 30 specialists from different disciplines in science, humanities, and arts. The scope of authors includes a wide range from Master and Ph.D. students, post-docs, scientists, humanists, theologists, engineers, jurists, economists to well-known artists, prominent authors and Nobel laureates. To date, JOSHA is publishing its $6^{\text {th }}$ volume. More than 120 articles have appeared and reached approximately 500,000 views and 400,000 downloads. The readership is primarily academic and steadily growing.

JOSHA can be reached through its website www.josha-journal.org and through social media networks Facebook and LinkedIn and Instagram. JOSHA is currently indexed in ROAD (Directory of Open Access Scholarly Resources), e-journal.org, and Scilit.

The journal supports two related projects, the Demetrios Project and the Demetrios Prize.

1. Demetrios Project: The project is named after Demetrius of Phaleron, a student of Theophrastus and most probably of Aristotle. He was instrumental in establishing the ancient Library of Alexandria, the largest and most significant library of the ancient world covering all aspects of Science, Humanities and the Arts in many different languages. The project is focused on publishing and providing open-access textbooks in any field of science, humanities, and arts, to students and readers worldwide after an appropriate review 
by experts in the field knowledgeable of the respective language. This initiative came up after IASHA board members and JOSHA editors felt that there is an urgent need to provide access to these materials especially to students and scientists in low and middle-income countries, in which textbooks are simply unaffordable by most students. With the July 2017 issue, the journal started the Demetrios Project with textbooks on architecture by Professor Bujar Bajçinovci, University of Pristina, Faculty of Civil Engineering and Architecture, Kosovo, written in the Albanian language. The journal encourages authors and readers to submit their textbooks for publication in JOSHA free of charge and to alert us to specific areas of need.

2. Demetrios Prize: This award is a competition related to the Demetrios Project that aims to support and promote the intellectual talent of young researchers from all universities around the world and making their works public in JOSHA. So far, the presentation of this literary and research contest has been carried out in 2018 and every year there are open registrations for all those who wish to participate and be part of the Demetrios Prize 2019. With this project we hope that young people will increase their interest in making research in their fields of work or even in making public the results of research previously done.

Description of the competition: For the categories BACHELOR, MASTER and DOCTORAL thesis, the International Academy of Science, Humanities and Arts (IASHA e.V.) supported by the BioThera-Roland-Mertelsmann Foundation selects three theses in each category and awards a prize of $€ 500$ each. The editors are in charge of the review of the articles submitted and the selection of the winners. The manuscripts of the winners are published in JOSHA, with a unique DOI for each paper. In 2018, submitted theses were in either German or English. In 2019, German, English, French or Spanish theses were submitted by mail to admin@josha-archive.org.

We are happy to carry on a successful way with all your support and hope to have a wonderful Sommer overflowing with endless interesting articles from all over the world. Together, we have achieved so much exile in such a short time. Therefore, we thank you and promise to continue to work to connect more authors around the world and continue to share important knowledge, because the knowledge that is not communicated is wasted knowledge! 

Humanities and Arts

The Editorial Board and everybody in JOSHA would like to thank our readers and authors for supporting this project. We wish all our readers a joyful reading experience at JOSHA!

Table of content: http://josha-journal.org/en/issues 